\title{
KARAKTERISTIK PERSETUJUAN DEWAN KOMISARIS TERHADAP KEWENANGAN DIREKSI MENJAMINKAN ASET PERUSAHAAN
}

\author{
Ryamirzad \\ Fakultas Hukum Universitas Airlangga \\ e-mail: ryamirzad@gmail.com \\ Galang Fauzan Prawinda \\ Fakultas Hukum Universitas Airlangga \\ e-mail: fauzan12prawinda@gmail.com
}

\begin{abstract}
ABSTRAK
Menjaminkan aset perusahaan adalah kewenangan direksi, namun kewenangan tersebut memiliki karakteristik tersendiri di dalam anggaran dasar sebuah perusahaan. Notaris yang memiliki kewenangan membuat akta jaminan tentunya akan menerapkan prinsip kehati-hatian dalam membuat produk hukumnya. Salah satu prinsip kehati-hatian yang digunakan oleh Notaris sebelum membuat akta jaminan bagi perusahaan ialah meminta bukti persetujuan dewan komisaris dalam wujud akta autentik walaupun sebenarnya bentuk persetujuan tersebut dapat dibuat dalam bentuk persetujuan di bawah tangan. Mengingat aset perusahaan memiliki peran yang penting bagi suatu perusahaan, tentunya akan ada batasan-batasan tersendiri yang wajib diatur oleh seorang komisaris manakala seorang direksi akan menjaminkan aset suatu perusahaan. Batasan-batasan tersebut adalah batasan nilai aset yang tentunya adalah aset-aset perusahaan yang bernilai tinggi. Tentunya bentuk persetujuannya dibuat dengan memperhatikan aturan yang berlaku agar memberikan kepastian dan perlindungan hukum. Oleh karenanya dalam penelitian ini akan dicari karakteristik bentuk persetujuan komisaris kepada direksi ketika menjaminkan aset perusahaan sebagai rumusan permasalahannya. Penelitian ini merupakan penelitian normatif. Hasil yang didapatkan dari penelitian ini adalah bentuk persetujuan komisaris kepada direksi dengan akta otentik akan lebih dapat memberikan keamanan dalam kegiatan berbisnis.
\end{abstract}

Kata Kunci: Persetujuan Dewan Komisaris; Direksi; Fidusia

\begin{abstract}
Guaranteeing company assets is the authority of the board of directors, but this authority has its own characteristics in the articles of association of a company. Notaries who have the authority to make guarantee deeds will certainly apply the principle of prudence in making their legal products. One of the precautionary principles used by a notary before making a deed of guarantee for a company is to ask for proof of approval from the board of commissioners in the form of an authentic deed even though in fact the form of agreement can be made in the form of an underhand agreement. Given that a company has an important role for a company, of course there will be its own limitations that must be regulated by a commissioner when a director will pledge the assets of a company. These limits are limits on the value of assets which of course are high value company assets. Of course, the form of approval is made by taking into account the applicable rules in order to provide legal certainty and protection. Therefore, this research will look for the characteristics of the form of approval from the commissioners to the directors when pledging the company's assets as a formulation of the problem. This research is a normative research. The results obtained from this study are the form of commissioner approval to directors with an authentic deed will provide more security in doing business.
\end{abstract}

Keywords: Board of Commissioners Approval; Directors; Fiduciary 


\section{PENDAHULUAN}

Salah satu bentuk badan hukum adalah perseroan terbatas. Perseroan terbatas yang merupakan badan hukum tercipta karena sistem konsesi dari Menteri berdasarkan Undang-Undang Nomor 40 Tahun 2007 tentang Perseroan Terbatas (selanjutnya disebut UUPT), di mana dalam Pasal 1 angka 1 UUPT dinyatakan bahwa Perseroan Terbatas adalah badan hukum yang merupakan persekutuan modal, didirikan berdasarkan perjanjian, melakukan kegiatan usaha dengan modal dasar yang seluruhnya terbagi dalam saham dan memenuhi persyaratan yang ditetapkan dalam Undang-Undang ini serta peraturan pelaksanaannya. Dalam Pasal 1 angka 2 UUPT disebutkan bahwa organ dalam perseroan terdiri dari Rapat Umum Pemegang Saham (RUPS), Direksi dan Dewan Komisaris. Masing-masing organ perseroan ini memiliki tugas dan kewenangan yang berbeda, mereka juga memiliki fungsi dan tanggung jawab sendiri-sendiri, di mana tiap organ tidak bisa mencampuri fungsi dan kewenangan organ lainnya selama yang dilakukannya sudah sesuai dengan undang-undang dan anggaran dasar perseroan.

Perusahaan dalam kegiatannya untuk mampu mempertahankan usahanya, tentu akan melakukan dan terlibat dalam transaksi yang mengharuskan perusahaan mengeluarkan dan/atau membutuhkan dana yang cukup besar untuk memenuhi kebutuhan dana tersebut. Salah satu contoh yang dapat dilakukan suatu perusahaan adalah melakukan kegiatan pembiayaan. Kegiatan tersebut dapat dilakukan melalui lembaga pembiayaan, baik lembaga pembiayaan bank maupun lembaga pembiayaan bukan bank (lembaga penyedia jasa keungan selain bank) yang memberikan jasa berupa pinjaman kredit, tentu dengan berbagai aspek hukum dan syarat yang sudah ditetapkan oleh pemberi pinjaman (kreditor) dan harus dipenuhi pemohon atau calon penerima pinjaman (debitor) agar mendapat pinjaman kredit/ dana.

Manakala suatu perjanjian itu melahirkan perikatan sebagaimana di atas, maka saat objek perikatan (prestasi) itu tidak dipenuhi, kreditor kemudian memiliki 4 (empat) pilihan, yaitu: 1 . Pemenuhan Perikatan; 2. Pembatalan Perikatan; 3. Pemenuhan Perikatan dengan Ganti Rugi; 4. Pembatalan Perikatan dengan Ganti Rugi. Manakala pihak debitor sudah wanprestasi, yang dipilih oleh kreditor adalah pemenuhan perikatan dengan ganti rugi. Inilah pada hakekatnya mengapa dalam utangpiutang ini ada urgensi disertakan jaminan, agar supaya proses pemenuhan perikatan dengan ganti rugi ini dapat berjalan dengan lebih mudah dan lancar.

Jaminan digunakan sebagai pengaman, dalam arti pemberi kepastian kepada kreditor saat memberikan persetujuan pemberian utang kepada debitornya. Karena pada kenyataannya, semua utang baik itu dengan menggunakan jaminan yang diikat secara sah, ataupun utang yang menggunakan jaminan namun tidak diikat secara sah, terlebih lagi utang yang tidak diikat lebih lanjut dengan jaminan, itu sangat berpotensi mengalami keterlambatan atau kendala dalam pembayarannya. Melalui pengikatan jaminan, utang dapat dilunasi dengan cara menjual objek yang diikat sebaga jaminan. Kendati demikian, ada batasan yang merupakan prinsip di mana itu tidak dapat dilanggar, yaitu pengikatan jaminan itu haruslah dilakukan dengan sah. ${ }^{2}$

Bentuk pengikatan jaminan tergantung dari benda jaminan itu sendiri apakah benda bergerak atau benda tidak bergerak, diantara bentuk pengikatannya ada Gadai, Fidusia, Hak Tanggungan dan Hipotek.

Undang-undang pokok perbankan yaitu Undang Undang Nomor 10 Tahun 1998 tentang Perubahan Atas Undang Undang Nomor 7 Tahun 1992 tentang Perbankan sangat menekankan arti pentingnya jaminan (Collateral) sebagai salah satu sumber pemberian kredit dalam rangka "pendistribusian" dana nasabah yang terkumpul olehnya, serta untuk menggerakkan roda perekonomian guna mendukung terus kegiatan bisnis yang mana kegiatan bisnis memiliki sifat dinamis yang terus berkembang memberikan kemudahan-kemudahan. ${ }^{3}$

Pada lembaga fidusia atau lembaga kepercayaan, yang dipindahkan atau diserahkan adalah hak atas benda secara kepercayaan, sedangkan bendanya sendiri masih tetap berada dalam kekuasaan pemilik benda, dengan demikian masih dapat dipergunakan

\footnotetext{
${ }^{1}$ Fani Martiawan Kumara Putra. "Konstruksi Lembaga Jaminan Untuk Saham Sebagai Bentuk Dukungan Perkembangan Bisnis". Perspektif. Vol. 23 No. 2 Tahun 2018, Edisi Mei, h. 68.

${ }^{2}$ Ibid., h. 69

${ }^{3}$ Gunawan Widjaja dan Ahmad Yani. (2001). Seri Hukum Bisnis, Jaminan Fidusia. Jakarta: PT. Raja Grafindo Persada, h. 73 .
} 
untuk kepentingan sehari-hari atau melanjutkan usaha debitur pemilik benda jaminan.

Pada umumnya benda yang dibutuhkan anggota masyarakat untuk menopang jalan hidupnya, adalah setiap benda yang punya nilai ekonomis dan hak miliknya dapat dialihkan. Benda dengan ciri seperti inilah yang akan dijadikan obyek transaksi dalam tatanan sosial. Menyangkut jenis transaksi dapat beraneka ragam, misalnya bisa berupa transaksi jual beli, sewa menyewa, peminjaman ataupun tukar menukar. ${ }^{4}$

Undang-Undang Nomor 42 Tahun 1999 tentang Fidusia (selanjutnya disebut UUJF) pada Pasal 5 ayat (1) UUJF menyebutkan bahwa Pembebanan Benda dengan Jaminan Fidusia dibuat dengan akta Notaris dalam bahasa Indonesia dan merupakan Akta Jaminan Fidusia, selanjutnya dipertegas dalam penjelasannya yang menyebutkan bahwa, di dalam suatu Akta Jaminan Fidusia selain mencantumkan hari dan tanggal, juga mencantumkan waktu (jam) pembuatan akta tersebut.

Adapun yang dimaksud dengan akta otentik menurut Burgerlijk Wetboek (selanjutnya disebut BW) ada pada Pasal 1868 BW, yakni: suatu akta otentik adalah suatu tulisan yang di dalam bentuknya ditentukan oleh undang-undang, dibuat oleh atau dihadapan pejabat umum yang berkuasa untuk itu dimana akta dibuatnya. Berbeda dengan Akta otentik, tulisan di bawah tangan yang dibuat secara bebas sebagaimana disebutkan dalam Pasal 1874 BW, bahwa yang dianggap sebagai tulisan dibawah tangan adalah akta yang ditandatangani di bawah tangan, surat, daftar, surat urusan rumah tangga dan tulisantulisan yang lain yang dibuat tanpa adanya perantara atau menghadap seorang pejabat umum (dalam hal ini adalah Notaris).

Notaris berwenang membuat akta otentik mengenai semua perbuatan, perjanjian dan ketetapan yang diharuskan oleh peraturan peraturan perundangundangan dan/atau yang dikehendaki oleh yang berkepentingan untuk dinyatan dalam akta otentik, menjamin kepastian pembuatan akta, menyimpan akta, memberikan grosse, salinan dan kutipan akta, semuanya itu sepanjang pembuatan akta-akta itu tidak juga ditugaskan atau dikecualikan kepada

\footnotetext{
${ }^{4}$ Moch. Isnaeni. (2017). Noktah Ambigu Norma Lembaga Jaminan Fidusia. Surabaya: Revka Petra Media, h. 12.
}

pejabat lain atau orang lain yang telah ditetapkan oleh Undang-Undang Jabatan Notaris.

Dalam kedudukannya saat ini, Lembaga Jaminan Fidusia yang dirasa sesuai dengan kebutuhan masyarakat, karena prosedurnya lebih mudah, lebih luwes, biayanya murah, selesainya cepat. Dengan kesadaran hukum yang semakin tinggi dan meningkatnya kebutuhan para subyek hukum akan legalitas suatu kegiatan usaha yang dijalankan, membuat peran Notaris sangat penting, karena adanya perjanjian kredit antara Kreditor dan Debitor dengan jaminan benda bergerak maka akan dilakukan perjanjian pengikatan jaminan dalam hal ini jaminan Fidusia. Jaminan Fidusia dibuat dengan akta Notaris antara pemberi Fidusia dan penerima Fidusia, sesuai dengan UUJF, jika debitur atau pemberi fidusianya badan hukum atau perusahan dalam hal ini perseroan terbatas, maka direktur atau dewan direksilah yang dapat mewakili perusahaan untuk melakukan perbuatan hukum tersebut.

Untuk menghindari adanya penyalahgunaan wewenang organ direktur, di dalam Pasal 117 ayat (1) UUPT disebutkan bahwa Direktur dalam melakukan perbuatan hukum tertentu harus melalui persetujuan dari Komisaris, apabila hal tersebut diatur dalam anggaran dasar perseroan. Penggunaan persetujuan Komisaris kepada Direktur untuk melakukan perbuatan hukum tertentu belum diatur atau ditentukan secara tegas harus secara Notariil atau bisa secara di bawah tangan. Dalam hal ini harus diperhatikan beberapa prinsip diantaranya prinsip itikad baik (good faith) dan kehati-hatian (prudential) yang semata-mata bertujuan untuk memajukan perseroan.

\section{PERUMUSAN MASALAH}

Karakteristik bentuk persetujuan komisaris kepada direksi ketika menjaminkan aset perusahaan.

\section{METODE PENELITIAN}

Penelitian ini merupakan penelitian normatif yang berarti penelitian ini meneliti mengenai sisi perundang-undangan itu sendiri, bukan meneliti mengenai gejala sosial akibat perundang-undangan yang ada. Metode pendekatan yang digunakan dalam penelitian ini adalah pendekatan perundangundangan (statute approach). Pembahasan ini akan mengacu pada undang-undang. 


\section{PEMBAHASAN}

Perseroan Terbatas merupakan badan hukum yang diakui oleh negara dan juga merupakan subjek hukum sebagaimana layaknya manusia yang dengan status itu perseroan terbatas mempunyai hak dan juga kewajiban, termasuk juga mempunyai harta kekayaam sendiri yang terpisah dari pendirinya baik berupa aset benda, uang maupun kekayaan yang lainnya, hanya saja terdapat hal-hal yang tidak dapat dilakukan oleh Perseroan Terbatas seperti manusia sebagai subjek hukum, hal itu adalah bahwa Perseroan Terbatas tidak bisa melakukan perkawinan layaknya manusia sebagai subjek hukum. Mulanya hanyalah subjek hukum peorangan atau individu yang dianggap memiliki hak dan kewajiban serta cakap hukum dan mampu melakukan perbuatan hukum, lalu badan hukum yang dalam istilah lain disebut juga artificial person, yaitu sesuatu atau suatu hal yang dalam tujuan penciptaannya oleh hukum memiliki tujuan untuk menuhi perkembangan dan yang timbul menjadi suatu kebutuhan dalam kehidupan bermasyarakat. ${ }^{5}$ Sebagai subjek hukum yang cipta untuk dapat melakukan suatu perbuatan hukum, maka hal itu dibuktikan dengan identitas. Layaknya manusia yang identitasnya disebut Kartu Tanda Penduduk (KTP). Perseroan sebagai subjek Hukum juga wajib memiliki identitas. Identitas pada Perseroan Terbatas disebut dengan akta pendirian.

Akta pendirian perseroan harus menyebutkan bahwa perseroan tersebut didirikan dengan maksud dan tujuan tertentu serta menjalankan memiliki kegiatan usaha yang tidak bertentangan dengan ketentuan peraturan perundang-undangan, etika atau dasar-dasar nilai dalam masyarakat, ketertiban umum, dan atau norma kesusilaan yang berlaku. Sebenarnya maksud dan tujuan didirikannya perusahaan adalah untuk mendapatkan keuntungan atau laba (Profit). Maksud, tujuan dan kegiatan usaha yang dilakukan atau dijalankan nantinya oleh Perseroan Terbatas (selanjutnya disebut PT) seharusnya sudah dijabarkan dan disebutkan dalam anggaran dasar perseroan tersebut. Anggaran dasar biasanya terdapat pada akta pendirian yang dibuat oleh Notaris. ${ }^{6}$

${ }^{5}$ Frans Satrio Wicaksono. (2009). Tanggung Jawab Pemegang Saham, Direksi, dan Komisaris Perseroan Terbatas. Malang: Visimedia, h. 2.

${ }^{6}$ Udin Silalahi. (2005). Badan Hukum dan Organisasi Perusahaan. Jakarta: Iblam, h. 35.
Akta pendirian yang di dalamnya tidak terdapat anggaran dasar maka akta pendirian tersebut dianggap tidak sah walaupun berbentuk akta Notaris (akta autentik) karena tidak memenuhi syarat materiil akta pendirian, sehingga akta tersebut tidak dapat memperoleh persetujuan atau pengesahan badan hukum dari kementrian hukum dan hak asasi manusia. Ketentuan-ketentuan lain terkait pelaksanaan, pengelolaan PT diantaranya:

1. Data diri atau identitas anggota Direksi, Dewan Komisaris dan Rapat Umum Pemegang saham (RUPS);

2. Ketentuan mengenai ketidakhadiran salah satu Direksi dalam tugasnya menjalankan PT yang melibatkan pihak ketiga dan tata cara kuasa;

3. Ketentuan apabila Dewan Komisaris lalai dan lepas dari tanggung jawabnya;

4. Jumlah kuorum yang dibutuhkan dalam Rapat Umum Pemegang Saham (RUPS); dan

5. Kewenangan dan tanggung jawab Direksi, Dewan Komisaris dan Rapat Umum Pemegang Saham (RUPS) juga batasan-batasan tugas.

Organ perseroan terdiri dari Rapat Umum Pemegang Saham (RUPS), Dewan Komisaris (jika terdapat lebih dari satu Komisaris) dan Direksi (jika terdapat lebih dari satu Direktur), dimana Rapat Umum Pemegang Saham (RUPS) merupakan pemegang kekuasaan atau jabatan tertinggi dalam perseroan, Dewan Komisaris merupakan wakil dari Rapat Umum Pemegang Saham (RUPS) yang melakukan pengawasan terhadap jalannya perseroan yang dijalankan oleh Direksi, dan Direksi sendiri adalah organ yang mewakili perseroan dalam melakukan perbuatan hukum baik di Pengadilan ataupun di luar Pengadilan. Rapat Umum Pemegang Saham (RUPS) walaupun memiliki jabatan tertinggi namun tidak bisa mengintervensi atau mempengaruhi Direksi dalam pengambilan keputusan terkait langkah-langkahnya dalam menjalankan atau melakukan kegiatan usaha perseroan.

Organ yang paling bertanggung jawab terhadap pengelolaan perusahaan adalah Direksi. Dalam Pasal 1 ayat (5) dinyatakan bahwa Direksi adalah organ yang berwenang dan bertanggung jawab penuh atas pengelolaan Perseroan untuk kepentingan Perseroan sesuai maksud dan tujuan Perseroan serta mewakili Perseroan, baik di dalam maupun di luar persidangan, apabila ada permasalahan hukum. 
Sebagai organ Perseroan Terbatas, Direksi mempunyai kedudukan, kewenangan atau memiliki kapasitas dan kewajiban seperti: ${ }^{7}$

1. Direksi memiliki fungsi melakukan kegiatan Perseroan, yang meliputi diantaranya:

a. Kegiatan PT dalam sehari-hari (menjalankan usaha); dan

b. Direksi berwenang melakukan pengelolaan dalam menjalankan kegiatan uasahanya atas nama perseroan.

2. Ruang lingkup Direksi menjalankan tugasnya mewakili perseroan, yaitu;

a. Dalam mewakili perseroan Direksi memiliki kewenangan yang luas dan tidak dapat diintervensi oleh pihak lain;

b. Setiap anggota Direksi punya kewenangan untuk mewakili perseroan dalam menjalankan kegiatan usahanya; dan

c. Untuk alasa tertentu Direksi dilarang mewakili perseroan.

Salah satu asas yang berlaku terkait dengan hukum perusahaan adalah ultra vires. Asas ini mempunyai arti yaitu organ perusahaan yang bertindak di luar kewenangannya (tercantum dalam anggaran dasar perusahaan) dalam menjalankan perusahaan atau juga tindakan organ perusahaan yang tidak dilarang namun hal tersebut bukanlah kewenangannya. Hal-hal yang dapat ditempuh secara hukum atau akibat hukum apabila terjadi Ultra Vires adalah:

1. Kontrak yang telah terjalin dan disepakati bisa dinyatakan batal oleh keduanya sehingga kedua pihak tidak terikat hak dan kewajiban atas kontrak tersebut;

2. Perusahaan dapat digugat oleh pemegang saham, bilamana pemegang saham berkehendak bahwa kontrak tersebut tidak boleh dilaksanakan;

3. Apabila sudah terjalin perjanjian kredit, kreditur dalam hal ini dapat meminta perjanjian tersebut dibatalkan jika ada indikasi telah terjadi ultra vires, dan ditakutkan bahwa aset kekayaan debitur tidak mampu untuk melunasi utangutangnya; dan

4. Direksi atau siapapun yang telah melakukan tindakan ultra vires pada suatu PT dapat digugat oleh perusahaan dan bertanggungjawab sampai

\footnotetext{
${ }^{7}$ M. Yahya Harahap. (2009). Hukum Perseroan Terbatas Jakarta: Sinar Grafika, h. 345.
}

dengan harta pribadinya, karena dalam perbuatan hukumnya dilakukan diluar kewenangannya.

Terdapat perlindungan hukum bagi pihak ketiga yang merasa dirugikan oleh perbuatan ultra vires suatu perusahaan, dengan catatan harus mempunyai itikad baik, yaitu:

a. Hak dan kewajiban kreditur tetap ada dan mengikat para pihak, selama pada saat perjanjian itu dibuat pihak kreditur tidak mengetahui adanya tindakan ultra vires;

b. Pihak kreditur diberikan hak untuk mendapat pengembalian dana yang telah diberikan kepada perusahaan jika perjanjian atau kontrak yang mengikat dua pihak dibatalkan; dan

c. Pihak kreditur dapat melakukan eksekusi terkait benda yang berada dalam jaminannya, namun tetap harus sesuai peraturan perundangundangan.

Notaris dalam menjalankan tugas dan wewenang guna membantu pemerintah yang mempunyai kewajiban untuk memberikan pelayanan ke masyarakat, melalui akta autentik yang dibuatnya dapat memberikan jaminan kepastian bagi masyarakat. Menjaga ketertiban di tengah masyarakat juga memunculkan suatu perlindungan hukum yang dibutuhkan masyarakat.

Akta autentik merupakan alat bukti yang kuat di dalam pengadilan yang dapat memberikan kepastian hukum atas permasalahan yang terjadi di dalam masyarakat baik dalam bentuk sengketa ataupun konflik antar warga, karena Notaris sendiri juga mudah ditemui di tengah-tengah masyarakat. Akta autentik dikatakan memiliki pembuktian yang kuat di pengadilan dan diangap sempurna karena bentuk dari akta autentik sudah ditentukan undangundang dan keabsahannya pun terjamin karena dibuat pejabat yang berwenang, dan kekuatan formil yang menyangkut di dalamnya (waktu, identitas para pihak dan akta yang dibubuhi tanda tangan atau cap jempol bagi yang tidak mampu tanda tangan dan saksi) sehingga akta tersebut merupakan fakta yang terjadi dan telah disepakati dan juga mengenai isi dalam akta yang memuat kebenaran.

Sebagian besar masyarakat masih banyak kurangnya menyadari arti pentingnya suatu dokumen sebagai alat bukti, guna mengetahui akibat hukum dari suatu kesepakatan atau perjanjian yang mereka buat. Mereka sering kali membuat sebuah 
kesepakatan di antara para pihak cukup melakukan dengan rasa saling kepercayaan dan dibuat secara lisan. Hal tersebut hanya dibuktikan dengan kesaksian dari beberapa orang saksi saja. Apabila terdapat suatu peristiwa atau kejadian yang memerlukan pembuktian kebenarannya yang mana para pihak yang berkepentingan memerlukan kesaksian, maka saksi-saksi tersebutlah yang akan memberikan dan membuktikan kebenarannya dengan kesaksiannya.

Akibat hukum dari kesaksian ini mempunyai kelemahan, selama para saksi itu masih hidup, maka tidak akan timbul hambatan, namun apabila saksi-saksi itu sudah tidak ada lagi, baik karena saksi sudah meninggal dunia atau sudah pindah ke tempat lain yang jauh dan tidak diketahui alamat tempat tinggalnya, maka akan timbul hambatan dalam melakukan pembuktian.

Tugas dari komisaris adalah melakukan pengawasan perusahaan. Pengawasan tersebut wujudnya adalah bentuk persetujuan dan/atau saran kepada direktur perusahaan dalam menjalankan perusahaan. Hal tersebut senada dengan Pasal 108 UUPT menegaskan bahwa Dewan Komisaris melakukan pengawasan atas kebijakan pengurusan, jalannya pengurusan pada umumnya, baik mengenai Perseroan maupun usaha Perseroan dan memberi nasihat kepada Direksi.

Seorang Direksi perusahaan dalam menjalankan tugasnya tidak hanya terbatas atas apa yang ada pada anggaran dasar perusahaan, melainkan juga dapat menjalankan kegiatan-kegiatan bisnis lainnya yang menyangkut kepentingan perusahaan. Hal tersebut secara tegas telah ada pada Pasal 92 UUPT yakni Direksi menjalankan pengurusan Perseroan untuk kepentingan Perseroan dan sesuai dengan maksud dan tujuan Perseroan.

Pasal yang mengatur mengenai maksud dan tujuan Perseroan hanyalah Pasal yang memberikan gambaran umum atas tujuan Perseroan. Hal tersebut tidak mungkin untuk menuliskan apa saja halhal teknis (kepentingan-kepentingan) yang akan dilakukan Perseoran untuk menuju maksud dan tujuan Perseroan. Salah satu contoh yang kepentingan yang mungkin mendukung Perseroan untuk mencapai maksud dan tujuannya adalah penambahan modal Perseroan.

Menambah jumlah modal suatu Perseroan merupakan salah satu contoh kepentingan perusahaan untuk dapat mencapai maksud dan tujuan. Namun terdapat hal yang wajib diperhatikan manakala akan membuat keputusan terkait hal tersebut. Hal yang wajib diperhatikan oleh seorang Direksi dalam mengambil keputusan yang mendukung kepentingan perusahaan adalah mengenai persetujuan organ perusahaan.

Mengingat bahwasannya selain direksi dan komisaris sebagai organ perusahaan, RUPS juga merupakan organ perusahaan yang memiliki peran yang sentral juga. RUPS dan Dewan Komisaris memiliki peran yang sentral dalam mendukung kebijakan-kebijakan yang dibuat oleh seorang direksi, dimana dalam hal ini seorang direksi akan melakukan penambahan modal perusahaan, yang mana dalam melakukan penambahan modal perusahaan tentu akan berkaitan dengan aspek jaminan. Tentunya objek yang akan dijadikan jaminan untuk menambah modal berasal dari aset perusahaan.

Pasal 102 ayat (1) UUPT memberikan penegasan terkait hal di atas, dimana ditegaskan bahwa Direksi wajib meminta persetujuan RUPS untuk: 1. Mengalihkan kekayaan Perseroan; atau 2. Menjadikan jaminan utang kekayaan Perseroan. Yang merupakan lebih dari 50\% (lima puluh persen) jumlah kekayaan bersih Perseroan dalam 1 (satu) transaksi atau lebih, baik yang berkaitan satu sama lain maupun tidak.

UUPT secara tegas memberikan batasan terkait tindakan-tindakan Direksi dalam menjalankan perusahaan, namun UUPT tidak secara tegas memberikan batasan terkait bentuk persetujuan kepada seorang Direksi dalam menjalankan perusahaan, baik itu melibatkan aset perusahaan lebih dari 50\% (lima puluh persen) maupun tidak lebih dari $50 \%$ (lima puluh persen). Hal tersebut dapat dilihat pada ketentuan Pasal 117 UUPT dimana ayat (1) menegaskan bahwa dalam anggaran dasar dapat ditetapkan pemberian wewenang kepada Dewan Komisaris untuk memberikan persetujuan atau bantuan kepada Direksi dalam melakukan perbuatan hukum tertentu. Dari narasi Pasal 117 ayat (1) UUPT tersebut akan menimbulkan keraguan bagaimana jika di dalam anggaran dasar Perseroan tidak mengatur bentuk persetujuannya. Namun keraguan tersebut dijawab oleh ayat selanjutnya yakni pada Pasal 117 ayat (2) yang menegaskan bahwa dalam hal anggaran dasar menetapkan persyaratan pemberian persetujuan 
atau bantuan sebagaimana dimaksud pada ayat (1), tanpa persetujuan atau bantuan Dewan Komisaris, perbuatan hukum tetap mengikat Perseroan sepanjang pihak lainnya dalam perbuatan hukum tersebut beritikad baik.

Ketentuan mengenai persetujuan perbuatan hukum seorang Direksi dalam menjalankan kewenangannya yang ada pada Pasal 117 UUPT berpotensi menimbulkan ketidakpastian hukum dan juga berpotensi adanya ketidakpastian hukum jika perbuatan hukum yang dilakukan Direksi hanya sebatas penilaian perbuatan Direksi dalam menjalankan perusahaan dengan itikad baik saja. Penilaian itu jika tidak dipersyaratkan secara tegas, baik oleh UUPT maupun oleh anggaran dasar Perseroan akan berpotensi memiliki akibat hukum yang tidak pasti. Walaupun oleh UUPT mekanisme persetujuan yang melibatkan aset-aset perusahaan yang lebih dari 50\% (lima puluh persen) diatur syarat kuorum persetujuannya, namun bentuknya tidak diatur, apalagi yang melibatkan aset perusahaan yang nilainya tidak lebih dari 50\% (lima puluh persen), akan sangat berpotensi menimbulkan ketidakpastian hukum, mengingat yang dinilai oleh UUPT adalah besaran aset perusahaan dalam jumlah persen. Manakala 5\% (lima persen) saja jumlahnya sudah menyentuh angka Milyaran, sudah sepatutnya hal tersebut juga diperhatikan oleh Komisaris dalam menjalankan pengawasan atas perbuatan hukum yang dilakukan oleh Direksi Perseroan.

Berdasarkan uraian tersebut di atas maka selayaknya bentuk persetujuan mengenai perbuatan hukum yang dilakukan oleh Direksi diatur juga wujudnya, yakni dalam bentuk akta yang dibuat secara otentik. dengan akta yang dibuat secara otentik akan memberikan kepastian hukum dan perlindungan hukum atas perbuatan-perbuatan hukum yang dilakukan oleh seorang Direksi, baik itu perbuatan hukum yang tidak melebihi 50\% (lima puluh persen) aset perusahaan atau yang melebihi 50\% (lima puluh persen) aset perusahan.

\section{PENUTUP}

\section{Kesimpulan}

Berdasarkan uraian-uraian yang telah dipaparkan di atas oleh para penulis, maka pada bagian penutup ini dapat diambil kesimpulan bahwa Bentuk persetujuan Dewan Komisaris kepada Direksi harus dibuat secara tertulis bahkan jika perlu secara akta otentik, baik yang melibatkan aset lebih dari 50\% (lima puluh persen) maupun melibatkan aset perusahaan yang tidak lebih dari 50\% (lima puluh persen), guna memberikan kepastian hukum dan perlindungan hukum dikemudian hari atas segala perbuatan hukum Direksi yang melibatkan aset perusahaan benar-benar dilakukan berdasarkan persetujuan dari Dewan Komisaris. Selain itu dengan dibuatnya segala persetujuan Dewan Komisaris kepada Direksi dalam wujud akta otentik, akan membuat seorang Direksi dalam menjalankan perusahaan tidak akan bisa melakukan perbuatan diluar kewenangannya mengingat konsekwensi hukumnya adalah pertanggungjawaban secara pribadi yang gugatannya dapat dilakukan oleh Dewan Komisaris maupun Perseroan itu sendiri sehingga tidak ada celah bagi Direksi melakukan ultra vires.

\section{Rekomendasi}

Pemerintah perlu memberikan regulasi khusus mengenai bentuk persetujuan dewan komisaris kepada dewan direksi khususnya terhadap kewenangan direksi menjaminkan aset perusahaan dimana bentuk persetujuan itu merupakan akta autentik agar dapat dipertanggungjawabkan di kemudian hari.

\section{DAFTAR BACAAN}

\section{Peraturan Perundangan-undangan:}

Undang-Undang Nomor 10 Tahun 1998 tentang Perubahan Atas Undang-Undang Nomor 7 Tahun 1992 tentang Perbankan.

Undang-Undang Nomor 42 Tahun 1999 tentang Jaminan Fidusia.

Undang-Undang Nomor 40 Tahun 2007 tentang Perseroan Terbatas.

Undang-Undang Nomor 2 Tahun 2014 Tentang Perubahan Atas Undang-Undang Nomor 30 Tahun 2004 tentang Jabatan Notaris.

\section{Buku:}

Burgerlijk Wetboek (BW).

Frans Satrio Wicaksono. (2009). Tanggung Jawab Pemegang Saham, Direksi, dan Komisaris Perseroan Terbatas. Malang: Visimedia.

Gunawan Widjaja dan Ahmad Yani. (2001). Seri Hukum Bisnis, Jaminan Fidusia. Jakarta: PT. Raja Grafindo Persada. 
M. Yahya Harahap. (2009). Hukum Perseroan Terbatas. Jakarta: Sinar Grafika.

Moch. Isnaeni. (2017). Noktah Ambigu Norma Lembaga Jaminan Fidusia. Surabaya: Revka Petra Media.

Udin Silalahi. (2005). Badan Hukum dan Organisasi Perusahaan. Jakarta: Iblam.

\section{Jurnal:}

Fani Martiawan Kumara Putra. "Konstruksi Lembaga Jaminan Untuk Saham Sebagai Bentuk Dukungan Perkembangan Bisnis". Perspektif. Vol. 23 No. 2 Tahun 2018, Edisi Mei, h. 68. 